Svatosova, V. (2020). The Importance of Online Shopping Behavior in the Strategic Management of E-Commerce Competitiveness. Journal of Competitiveness, 12(4), 143-160. https://doi.org/10.7441/ joc. 2020.04 .09

\title{
The Importance of Online Shopping Behavior in the Strategic Management of E-Commerce Competitiveness
}

\section{- Veronika Svatosova}

\begin{abstract}
In this article a total of fifteen determinants of online shopping behavior have been identified that could have an impact on the strategic management process in e-commerce competitiveness. The main objective of the paper is to evaluate the impact of determinants of online shopping behavior on the strategic management process in e-commerce. The main research methods used in the research are as follows: analysis of secondary data, a questionnaire survey among a selected group of e-commerce companies, a critical analysis and a quality comparison of the actually applied determinants of online shopping behavior. The verification of hypotheses is realized using selected methods of statistical induction and descriptive statistics. In summary, the research has shown there is no relationship between evaluating the quality of determinants companies in e-commerce and evaluating the importance of determinants of online shopping behavior. Determinants have an important impact in the process of creating and realizing an e-commerce strategy, with all e-commerce companies regardless of their size being aware of their practical impact and importance. It can be concluded the importance and quality of determinants of online shopping behavior correspond to the type of strategy and strategic management process in terms of e-commerce competitiveness.
\end{abstract}

Keywords: e-commerce, strategic management, online shopping behavior, e-strategy, determinants of online shopping behavior, e-commerce competitiveness

JEL Classification: M00, M30, M39

Received: February, 2020

1st Revision: September, 2020

Accepted: September, 2020

\section{INTRODUCTION}

The field of online shopping behavior has been the subject of many contemporary researches (Prashant, 2009; Kim et al., 2009; Wang et al., 2010; Roca et al., 2009; Martín \& Camarero, 2009; Pereira et al., 2016; Safa \& Ismail, 2013; Pilík et al., 2017a). These studies have dealt with factors concerning trust, loyalty and riskiness in e-commerce during online shopping processes. These research projects have also built up models of shopping behavior based on factors currently influencing the whole online process of online shopping behavior. All these studies have 
approached the process of online shopping behavior from the perspective of online customers or online users. No relevant research, however, has to our knowledge been published regarding online buying behavior from the perspective of online retailers (in neither the $\mathrm{B} 2 \mathrm{C}$ market nor B2B market).

This paper focuses on studying the determinants of online buying behavior from the perspective of companies primarily focused on e-commerce. Significant knowledge concerning the importance of online shopping behavior from the business perspective and its impact on the strategic management process has not yet been developed. Therefore, the main aim of the paper is to evaluate the impact of determinants of online shopping behavior on the strategic management process in e-commerce competitiveness.

The paper is focused first on the identification of 15 determinants of online shopping behavior based on results of secondary researches (Pilík, 2012; Pilík et al., 2017a; Pilík et al., 2017b; Prashant, 2009; Richard et al., 2010; Huang \& Benyoucef, 2013; Roberts \& Zahay, 2013; Lu et al., 2015; Huseynov \& Yildirim, 2016; Hallikainen \& Laukkanen, 2018; Dai, 2012; Choshin \& Ghaffari, 2017; Kumar \& Dange; 2012; Singh \& Sailo, 2013; Cetina et al., 2012; Safa \& Ismail, 2013; Hernández et al., 2010; Makwana et al., 2017; Darsono et al. 2019; Li et al. 2019). Following this identification, the impact of these 15 determinants is evaluated in the process of strategic management of companies primarily focused on e-commerce by means of results from personal interviews along with critical quality analysis. The main research question is the following: do e-commerce companies consider determinants of online shopping behavior in the process of strategic management?

The main added value of the paper is based on the identification of determinants of online shopping behavior from the perspective of e-commerce companies and the impact in this identification on the process of strategic management in e-commerce competitiveness. These findings could serve as the basis for other research activities in this field as well as for digital managers and owners to improve the effectiveness of their strategic management processes toward ecommerce competitiveness.

\section{THEORETICAL BACKGROUND}

While it is influenced by many external and internal factors, consumer shopping behavior plays one of the key roles in establishing and achieving an enterprise's main objectives. Many offline retailers attempt to enter the e-commerce market through online stores, which are easily set up at low cost, to advertise and sell their products over the Internet (Kim et al., 2018; Dai, 2012; Chossin \& Ghaffari, 2017). Huseynov \& Yildirim (2016) have found that understanding the motives and factors of online consumers for online shopping leads to a successful determination and implementation of a marketing strategy on the Internet. Pilík et al. (2017a) confirmed that the main motive of online shoppers is to find a lower price as well as online shopping convenience and home shopping convenience. Older online buyers, however, focus more exclusively on shopping convenience. For companies engaging in s-commerce, building trust is very important, as customer experiences are often shared on social networks. For these companies, maintaining the high reputation of the firm's website is connected to the general reputation of the enterprise (Kim \& Park, 2013; Bandara et al., 2019). 
Research conducted over the past decade or so only supports these theories in part. The interaction between a national culture and trust factors may vary significant among nations (Hallikainen \& Laukkanen, 2018; Hernandéz et al., 2010). It is at times very important for the buyer to gather enough product information before buying, especially in the case of a relatively expensive product. In this situation, engaging in e-commerce might seem disadvantageous, thus for this reason, shopping assistance systems and various price comparison systems have been developed. Most Czech customers prefer online shopping in stores mainly because of lower prices (Pilík et al., 2017a; Castaneda et al., 2009). Promotional prices are among the most important factors influencing a consumer's decision to buy online, as promotional campaigns that offer lower prices have a positive effect on sales growth, although they can also significantly reduce company profits (Pilík et al., 2017b). The second most important factor when shopping online is convenience, since online services are always available and the goods are usually delivered to their destination, helping customers to save time. A third significant factor of online shopping is the ability to quickly compare goods (Pilík et al., 2017a; Petrtyl, 2012). E-commerce logistics professionals face various challenges in fulfilling customer online orders in $\mathrm{B} 2 \mathrm{C}$ markets, as the e-commerce fulfillment process is significantly different from the traditional shipment process. (Leung et al., 2018; Broome, 2016, Cetina et al., 2012).

As the area of e-commerce is gaining more importance in the current business environment, the needs for effective e-commerce strategy along with the process of strategic management is increasing (Yanes-Estévez et al., 2018; Lynda et al., 1996; Singh \& Sailo, 2013). The key element of a successful process of strategic management in e-commerce is to identify determinants in e-commerce that influence the overall process; this determination is a prerequisite for the long-term development of e-commerce businesses. Nevertheless, only minor research studies (Zhao et al., 2020; Wang et al., 1019; Zhao et al., 2019) have dealt with the crucial determinants influencing the effective process of strategic management which lead to effective e-commerce strategy implementation. Most of these studies (Singh \& Keating, 2018; Oliva et al., 2003; Kao \& Decou, 2003) focus on online activities in e-commerce, i.e. mainly online marketing and selected managerial activities, i.e. what is missing is the comprehensive strategic approach in e-commerce focusing on interactions between online and offline strategic behavior.

The main motivation for the research described in this paper is the knowledge gap regarding explorations of the importance of strategy and strategic approaches in e-commerce, especially the identification and importance of determinants of online shopping behavior in e-commerce and their impact on the long-term development and e-commerce competitiveness of companies. Determinants of online shopping behavior are crucial in terms of effective and successful process of strategic management in e-commerce (Li, 2015; Long, 2017; Chouhan, 2017; Onate, 2016; Yi, 2016; Lee, 2001). With the latest trends in online shopping and online trading, the importance of an effective strategic management process in e-commerce is growing even more. Nevertheless, practical studies show that the importance of e-strategy in the long-term development is underestimated. A prerequisite for a successful e-commerce strategy is an effective process of strategic management in e-commerce competitiveness (Wu \& Wu, 2015; Perrigot \& Pénard, 2013; Zwas, 2003; Lumpkin et al., 2002). An important aspect of an effective strategic management process, not only in e-commerce, is the identification of determinants that affect the entire process (Forman, 2005; Doern \& Fey, 2006; Power, 2005; Filson, 2004; Ivanova et al., 2019). 


\section{RESEACH OBJECTIVE, METHODOLOGY AND DATA}

\subsection{Material and methods}

The main aim of the research is to evaluate the impact of determinants of online shopping behavior on the strategic management process of companies primarily focused on e-commerce in their long-term development and competitiveness. The partial aim of the research is to evaluate the quality of determinants of online shopping behavior, which the monitored companies primarily oriented on e-commerce for their online customers, comparing the quality of these determinants and evaluating the importance of determinants of online shopping behavior within the questionnaire survey. The research output is the identification of determinants of online shopping behavior influencing the process of creating and implementing a strategy in e-commerce. The main research methods include the analysis of secondary data from research conducted by the Association for Electronic Commerce, the Czech Statistical Office and other relevant research studies, data used from the research in the form of a questionnaire, critical analysis and a quality comparison of actually applied determinants of online shopping behavior in the Czech ecommerce environment (for details, see Results and Discussion). As for the hypotheses verification, the following methods of statistical induction are used: Kruskal-Wallis test, Friedman test, methods of correlation matrix. The identification and verification of hypotheses are discussed in more detail in the chapter Results and Discussion.

The research (especially questionnaire survey) was conducted during the year 2019 with CEOs and owners of selected companies primarily oriented to e-commerce (for details, see Research Sample), i. e. personalities responsible for strategy creation and implementation within a strategic management process in e-commerce, firstly by e-mail and telephone, upon the mutual agreement, the electronic questionnaire was sent to them. First of all, a preliminary survey was conducted among eight selected companies in order to confirm the comprehensibility of the questionnaire (especially the knowledge and implications for the evaluated determinants). The main goal of the questionnaire was to find out how selected determinants of online shopping behavior affect the process of strategic management in their long-term development and competitiveness in e-commerce. The theoretical explanations of selected determinants were sent together with the questionnaire. The aim of the questionnaire survey was to find out the view of selected e-commerce businesses on the importance of 15 identified determinants of online shopping behavior in their long-term development and competitiveness in e-commerce.

\subsection{Identification of determinants of online shopping behavior}

Based on the results of the literature review, the following factors of online shopping behavior can be identified, which may influence the strategic approach in e-commerce most and in the long term Pilík, 2012; Pilík et al., 2017a, Pilík et al., 2017b; Prashant, 2009; Richard et al., 2010; Huang \& Benyoucef, 2013; Roberts \& Zahay, 2013; Lu et al., 2015; Huseynov \& Yildirim, 2016; Hallikainen \& Laukkanen, 2018; Dai, 2012; Choshin \& Ghaffari, 2017; Kumar \& Dange, 2012; Singh \& Sailo, 2013; Cetina et al., 2012; Safa \& Ismail, 2013; Hernández et al., 2010; Makwana et al., 2017): 1) E-commerce security for the buyer and seller; 2) Internet payment options; 3) the method and speed of delivery of goods; 4) e-shop web design (e-shop user interface);5) the intensity of interactive communication with the customer; 6) e-shop credibility; 7) e-shop certi- 
fication; 8) online visualization and product description on the e-shop; 9) added value to online purchase (customer service); 10) e-shop reference and discussion; 11) product reference and discussion; 12) multi-channel sales (online store together with a physical store); 13) the lower price of products or services; 14) unlimited purchase time; 15) a wider range of products.

\subsection{Research sample}

A research sample of companies was identified according to the following criteria:

1. SMEs and large companies in e-commerce;

2. Companies trading mainly through websites;

3. Companies selling on the $\mathrm{B} 2 \mathrm{C}$ market. Companies offering physical products;

4. Their main sat id in the Czech Republic;

5. Legal form of business: Joint Stock Company, Limited Liability Company;

6. Existence of the companies on the market - at least 7 years (i.e. established in 2011 and earlier);

7. Membership of companies in the Association for Electronic Commerce or certification of a customer-verified award by Heuréka.cz);

8. Companies with one or more full-featured e-shop.

The research sample is limited to the established e-commerce companies, in which there is a prerequisite of strategy approaches creation and identification. This research sample also limits to the Czech e-commerce companies with a future plan to compare the findings with other countries. Finally, the research sample counts 367 companies, fulfilling the criteria mentioned above. Finally, 209 companies were participated the survey. The return ability in this survey was $56.9 \%$. Using the application Raosoft (2018), at a 95\% confidence level and 5\% error tolerance, a representative sample should be 188 respondents. Companies participated are divided according to their size: micro companies (up to 10 employees), small companies (up to 50 employees), medium companies (up to 250 employees), large companies (up to 500 employees) and large companies + (over 500 employees).

\section{RESULTS AND DISCUSSION}

\subsection{Results of the survey}

Companies evaluated the influence of selected determinants of online shopping behavior on their long-term development and competitiveness and on the strategic management process in e-commerce selected on a scale 1 - 5 ( 1 - the least important, 5 - the most important). These determinants of online shopping behavior are also the subject of this part of research, whose main aim is to assess the quality of these determinants that the monitored companies apply to their online customers. The quality rating of the selected determinants is evaluated on a scale of $1-5$ ( 1 - the lowest quality, 5 - the best quality). This evaluation on the scale $1-5$ is the subject of statistical testing (conversion of qualitative data into the numerical value). The individual quality 
of the identified determinants of online shopping behavior is evaluated for each participating enterprise. The results of the critical analysis and observations in this part of research are compared according to the size of companies primarily oriented to e-commerce, i.e. micro companies (51 in total), small companies (85 in total), medium companies (41 in total), large companies (12 in total) and large + companies (20 in total). In summary, 209 companies participated in the questionnaire survey and critical qualitative analysis. The aim of the rating scale is to transform the determinants of online shopping behavior into objective value. The aim of the evaluation is to provide a qualitative assessment of determinants of online shopping behavior that take into account e-commerce companies to a single numerical value. An enterprise that scores low in some determinants does not mean that it is of poor quality, but it should generally achieve at least an average rating that is indicative of trying to adapt online customer behavior. The results of the quality evaluation and critical analysis of determinants of online shopping behavior are shown in Figure 1 divided by enterprise size (micro, small, medium, large and large + ). Subsequently, these values are compared with the evaluation of the importance of these determinants of online shopping behavior by the companies from the questionnaire survey themselves. On average, the quality of determinants of online shopping behavior based on critical analysis is better for evaluation than the evaluation of the importance of these determinants by monitored companies.

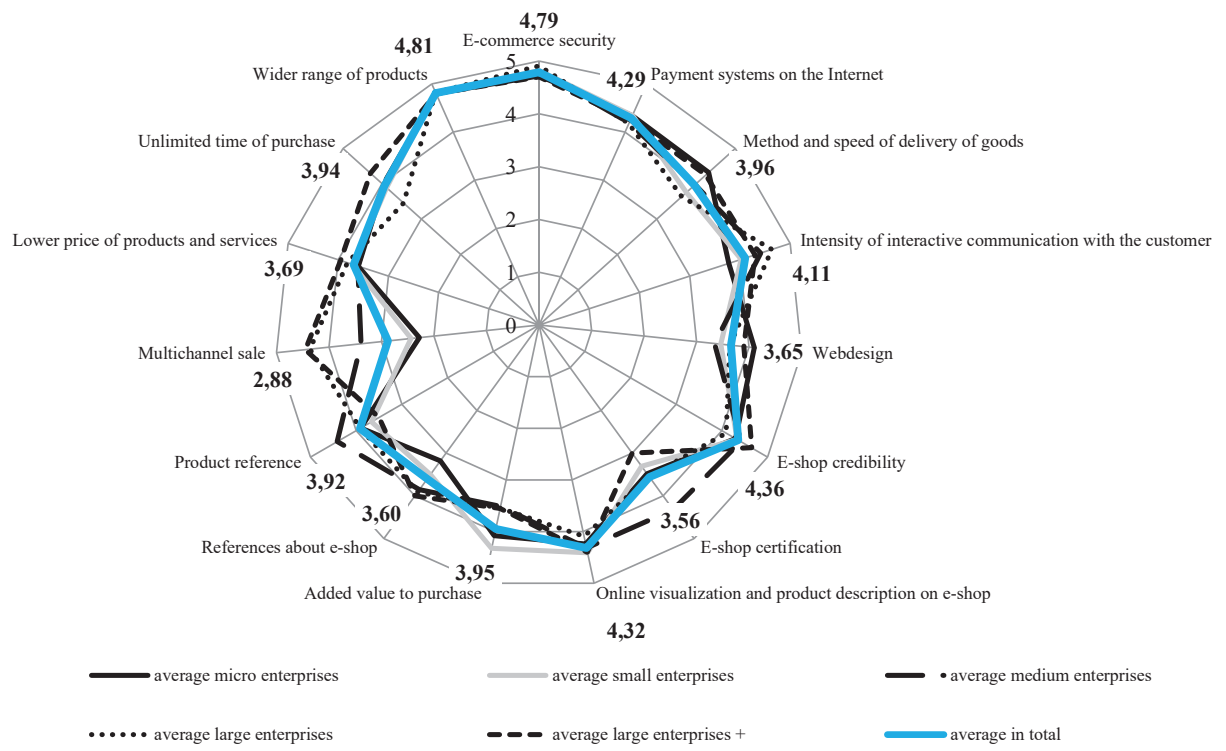

Fig. 1 - Average quality evaluation of determinants of online shopping behavior by enterprise size. Source: own research

The previous part of the questionnaire survey also dealt with the question of the importance of determinants of online purchasing behavior in strategic management in e-commerce attributed to companies primarily oriented to e-commerce. This question was asked in the questionnaire survey to compare the actual quality evaluation of determinants of online shopping behavior. An 
evaluation of the significance of determinants of online shopping behavior is given in Figure 2 . The most important ones are online visualization and product description in the e-shop (3.44), e-shop certification (3.39), the lower price of products and services (3.12) and web design (3.12). On the other hand, multi-channel sales (2.95), a wider range of products (2.97), payment systems on the Internet (3.00) and an unlimited time of purchase (3.01) are the least significant.
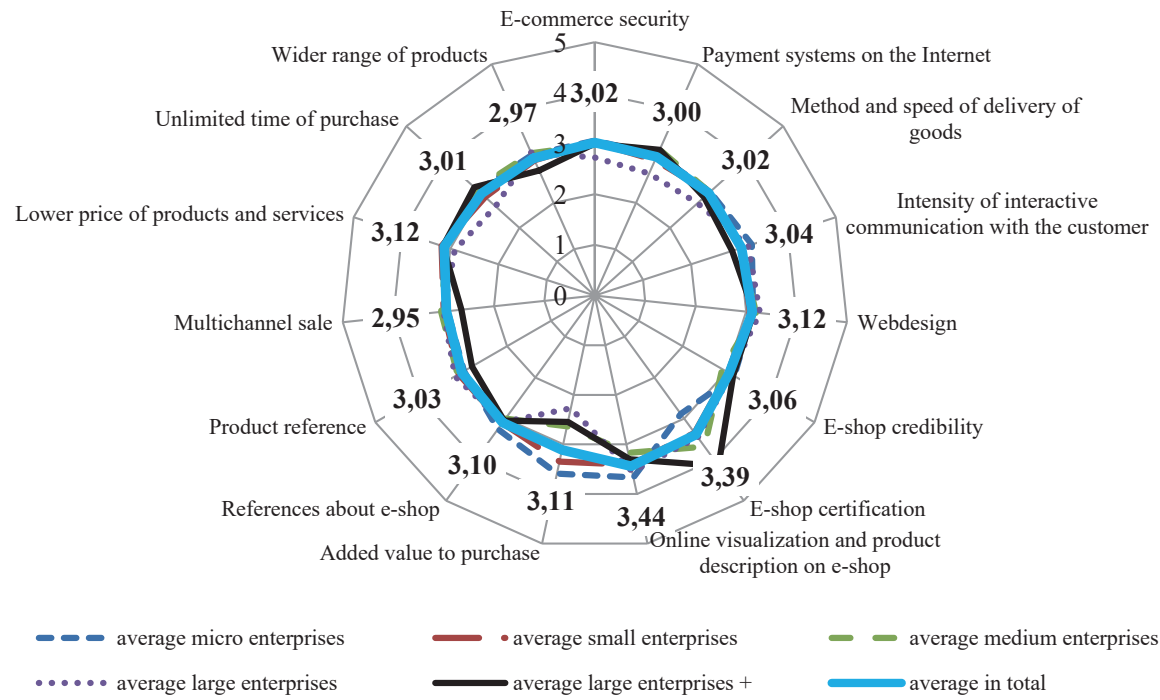

Fig. 2 - Average evaluation of the importance of determinants of online shopping behavior for strategic management in e-commerce. Source: own research

\subsection{Hypotheses verification}

The following chapter examines the main and partial hypotheses of the research. Hypothesis testing is realized at the significance level of $\alpha=0.05$. The verification of hypotheses is realized by comparing the p-value, which is the minimum significance level for which the null hypothesis is rejected at the significance level $\alpha$. The Shapiro-Wilk test was used and declared the variety (tested for each separate identified determinant of online shopping behavior, in summary 15 tests of normality have been done) did not come from a normal probability distribution at the significance level of $\alpha=0.05$, since $\mathrm{p} \leq \alpha$ (based on software Statistica results). As the normality condition is not met, neither the variance analysis nor correlation tests, such as the Pearson correlation coefficient, can be performed. The limitations of non-parametric tests are as follows: the conclusions of these methods are less reliable than those of parametric methods; confidence intervals are usually larger, the set level of significance is usually observed with too much margin, tests have less power (Kubanová, 2004). The following non-parametric tests are selected for hypothesis testing: the Kruskal-Wallis test, correlation matrix (multiple selection coefficient) and the Friedman test. The hypotheses are verified by the software Statistica (Kubanová, 2004). The hypotheses validated are referred to as the null hypothesis (H0), which expresses no or 
zero difference between the data sets tested. If the null hypothesis cannot be confirmed, then the alternative hypothesis (H1) is tested against the null hypothesis. An alternative hypothesis expresses the existence of a difference between sets or the existence of a dependency between variables (Kubanová, 2004). The results of the questionnaire survey are divided according to the size of companies. Furthermore, the results of the questionnaire survey are divided according to the size of the assets of companies.

\subsection{Summary of the main and partial research hypotheses}

The Table 1 give the main outcomes and verify the research hypotheses based on the previous results of the primary research and the verification of the main and partial research hypotheses. The following variables were used for testing the hypotheses: 1) quality of 15 identified determinants of online shopping behavior (based on critical quality analysis of 209 companies) selected on a scale of $1-5$ ( 1 - the lowest quality, 5 - the best quality); 2) importance of 15 identified determinants of online shopping behavior selected on a scale 1 - 5 (1 - the least important, 5 the most important), (based on the results of the questionnaire survey of 209 companies); 3) variables of economic performance of selected 209 companies (WACC, ROA, ROE, current liquidity, long-term coverage based on financial analysis from financial statements); 4) size of selected companies divided into the following categories: micro companies (up to 10 employees), small companies (up to 50 employees), medium companies (up to 250 employees), large companies (up to 500 employees) and large companies + (over 500 employees); 5) importance of individual phases of strategic management in e-commerce, i.e. analysis, identification and formulation of strategy, planning, implementation, control selected on a scale 1 - 5 (1 - the least important, 5 - the most important).

Descriptive statistics and verification of research hypotheses have revealed that there is a relationship between the size of an enterprise and the quality of determinants of online shopping behavior. Furthermore, it was found out that the evaluation of the quality of determinants of online shopping behavior based on critical analysis is not evenly distributed and the quality of determinants of online shopping behavior does not affect the importance of various phases of strategic management in e-commerce. The same results were achieved in the search for the context and relationship of determinants and other variables and the importance of determinants of online shopping behavior in e-commerce by companies primarily oriented to e-commerce. It has been also shown that the importance of determinants of online shopping behavior is not evenly distributed; there is no correlation between the importance of the e-commerce strategy and the importance of these determinants of online shopping behavior. On average, the determinants of online shopping behavior are rated as less significant than their quality itself, based on the critical analysis results. These findings could be explained by the fact that these determinants are considered to be a necessity in designing the implementation e-strategy in the strategic management process in e-commerce.

Based on the main and partial hypotheses verification, it can be concluded that the determinants of online shopping behavior are part of the strategic management process in e-commerce and play the key role in designing and implementing an e-commerce strategy in the long-term development of companies primarily focused on e-commerce. All companies (regardless of their size) 
are aware of the importance of these determinants in their strategic approach and competitiveness in e-commerce. Therefore, in practice, the strategic management process in e-commerce is influenced by the determinants of online shopping behavior. In summary, e-commerce companies could not survive in the long-term period without considering these determinants of online shopping behavior in the strategic management process in e-commerce. Based on critical qualitative analysis, these determinants are high-quality evaluated, since the selected companies belong to the established and experienced companies with their own e-strategy aware of the importance of these determinants in the long-term development in e-commerce. In can be concluded that e-commerce companies could be in the long-successful term without considering determinants of online shopping behavior in the strategic management process.

Tab. 1 - Main and partial hypotheses verification - summary. Source: own research

\begin{tabular}{|c|c|c|c|c|}
\hline \multicolumn{5}{|c|}{ Main research hypotheses $(\mathrm{MH})$ and partial research hypotheses $(\mathrm{PH})$ of the research } \\
\hline \multicolumn{5}{|c|}{$\begin{array}{l}\text { Main research hypothesis } \\
\text { MH: Companies primarily oriented to e-commerce do not take into account the main determinants of on- } \\
\text { line shopping behavior when designing and implementing an e-commerce strategy in the strategic manage- } \\
\text { ment process in e-commerce. } \\
\text { Conclusion of hypothesis verification: Rejected }\end{array}$} \\
\hline \multicolumn{2}{|c|}{ Partial research hypothesis } & Method* & $\begin{array}{l}\text { P-value based on results of software Sta- } \\
\text { tistica }\end{array}$ & $* *$ \\
\hline $\mathrm{PHa})$ & $\begin{array}{l}\text { The importance of determi- } \\
\text { nants of online shopping be- } \\
\text { havior is not influenced by the } \\
\text { size of companies primarily } \\
\text { oriented to e-commerce.* }{ }^{*} \text { Te- } \\
\text { sting this hypothesis was re- } \\
\text { alized for each separate tes- } \\
\text { ted determinant. Some of the- } \\
\text { se determinants were rejected } \\
\text { and some not rejected, howe- } \\
\text { ver this hypothesis was tested } \\
\text { as a whole for } 15 \text { identified de- } \\
\text { terminants in summary, there- } \\
\text { fore, this hypothesis was as a } \\
\text { whole rejected. }\end{array}$ & 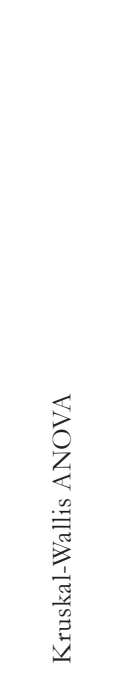 & $\begin{array}{l}\text { E-commerce security: } \mathrm{p}=0.9877 \\
\text { Payment systems in e-commerce: } \\
\mathrm{p}=0.8194 \\
\text { Method and speed of delivery of goods: } \\
\mathrm{p}=0.9534 \\
\text { Webdesign: } \mathrm{p}=0.7396 \\
\text { Customer service: } \mathrm{p}=0.9828 \\
\text { E-shop credibility: } \mathrm{p}=0.8990 \\
\text { E-shop certification: } \mathrm{p}=0.0029 \\
\text { Online visualization and product descrip- } \\
\text { tion: } \mathrm{p}=0.4719 \\
\text { Added value to online purchase: } \\
\mathrm{p}=0.0010 \\
\text { E-shop reference: } \mathrm{p}=0.8986 \\
\text { Product reference: } \mathrm{p}=0.9248 \\
\text { Multi-channel sales: } \mathrm{p}=0.8844 \\
\text { Lower price of products and services: } \mathrm{p} \\
=0.9949 \\
\text { Wider range of products: } \mathrm{p}=0,7331 \\
\text { Unlimited time of purchase: } \mathrm{p}=0.8403\end{array}$ & 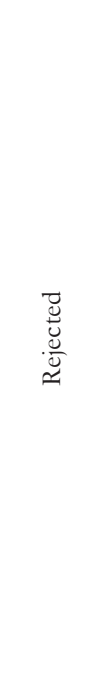 \\
\hline
\end{tabular}




\begin{tabular}{|c|c|c|c|c|}
\hline PHb): & $\begin{array}{l}\text { The type of e-commerce stra- } \\
\text { tegy is not influenced by the } \\
\text { importance of determinants of } \\
\text { online shopping behavior.* } \\
\text { *Testing this hypothesis was } \\
\text { realized for each separate tes- } \\
\text { ted determinant. Some of the- } \\
\text { se determinants were rejected } \\
\text { and some not rejected, howe- } \\
\text { ver this hypothesis was tested } \\
\text { as a whole for } 15 \text { identified de- } \\
\text { terminants in summary, there- } \\
\text { fore, this hypothesis was as a } \\
\text { whole rejected.. }\end{array}$ & 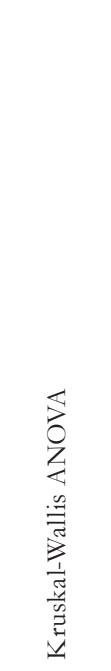 & $\begin{array}{l}\text { E-commerce security: } \mathrm{p}=0.9756 \\
\text { Payment systems in e-commerce: } \mathrm{p}= \\
0.6275 \\
\text { Method and speed of delivery of goods: } \\
\mathrm{p}=0.0015 \\
\text { Webdesign: } \mathrm{p}=0.1256 \\
\text { Customer service: } \mathrm{p}=0.4773 \\
\text { E-shop credibility: } \mathrm{p}=0.0096 \\
\text { E-shop certification: } \mathrm{p}=0.7384 \\
\text { Online visualization and product descrip- } \\
\text { tion: } \mathrm{p}=0.7792 \\
\text { Added value to online purchase: } \\
\mathrm{p}=0.0343 \\
\text { E-shop reference: } \mathrm{p}=0.0489 \\
\text { Product reference: } \mathrm{p}=0.9576 \\
\text { Multi-channel sales: } \mathrm{p}=0.2759 \\
\text { Lower price of products and services: } \\
\mathrm{p}=0.7465 \\
\text { Wider range of products: } \mathrm{p}=0.5647 \\
\text { Unlimited time of purchase: } \mathrm{p}=0.4993\end{array}$ & 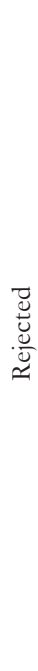 \\
\hline PHc): & $\begin{array}{l}\text { All determinants of online } \\
\text { shopping behavior are con- } \\
\text { sidered equally important by } \\
\text { companies primarily oriented } \\
\text { to e-commerce. }\end{array}$ & 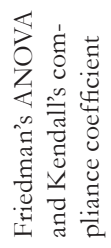 & $\mathrm{p}=0.01556$ & 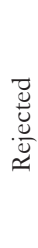 \\
\hline PHd): & $\begin{array}{l}\text { There is no relationship } \\
\text { between the importance of the } \\
\text { different phases** of strategic } \\
\text { management (analysis, strate- } \\
\text { gy preparation and formulati- } \\
\text { on, planning, implementation, } \\
\text { control) in } \\
\text { e-commerce and the impor- } \\
\text { tance of online determinants } \\
\text { of online shopping behavior. } \\
\text { **evaluated as the average } \\
\text { mean of selected determinants } \\
\text { for each phase of strategic ma- } \\
\text { nagement in e-commerce. }\end{array}$ & 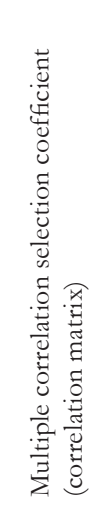 & $\begin{array}{l}\text { Multiple } \mathrm{p} \text {-values in correlation matrix, } \\
\text { since } \mathrm{p} \leq \alpha\end{array}$ & 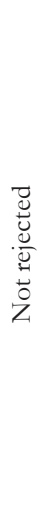 \\
\hline PHe): & $\begin{array}{l}\text { There is no relationship } \\
\text { between the quality of the de- } \\
\text { terminants of online shopping } \\
\text { behavior of companies pri- } \\
\text { marily oriented to e-commer- } \\
\text { ce and the importance of the } \\
\text { determinants of online shop- } \\
\text { ping behavior rated by com- } \\
\text { panies primarily oriented to e- } \\
\text { commerce }\end{array}$ & 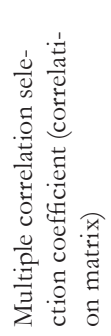 & $\begin{array}{l}\text { Multiple } \mathrm{p} \text {-values in correlation matrix, } \\
\text { since } \mathrm{p} \leq \alpha\end{array}$ & 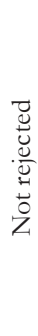 \\
\hline
\end{tabular}




\begin{tabular}{|c|c|c|c|c|}
\hline PHf): & $\begin{array}{l}\text { The quality of determinants } \\
\text { of online shopping behavior } \\
\text { is not influenced by the size of } \\
\text { companies primarily oriented } \\
\text { to e-commerce.* } \\
\text { *Testing this hypothesis was } \\
\text { realized for each separate tes- } \\
\text { ted determinant. Some of the- } \\
\text { se determinants were rejected } \\
\text { and some not rejected, howe- } \\
\text { ver this hypothesis was tested } \\
\text { as a whole for } 15 \text { identified de- } \\
\text { terminants in summary, there- } \\
\text { fore, this hypothesis was as a } \\
\text { whole rejected. }\end{array}$ & 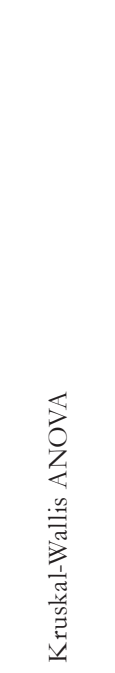 & $\begin{array}{l}\text { E-commerce security: } \mathrm{p}=0.5651 \\
\text { Payment systems in } \mathrm{e} \text {-commerce: } \mathrm{p}= \\
0.8294 \\
\text { Method and speed of delivery of goods: } \\
\mathrm{p}=0.0191 \\
\text { Webdesign: } \mathrm{p}=0.0068 \\
\text { Customer service: } \mathrm{p}=0.0010 \\
\text { E-shop credibility: } \mathrm{p}=0.4365 \\
\text { E-shop certification: } \mathrm{p}=0.0570 \\
\text { Online visualization and product descrip- } \\
\text { tion: } \mathrm{p}=0.9513 \\
\text { Added value to online purchase: } \mathrm{p}= \\
0.0000 \\
\text { E-shop reference: } \mathrm{p}=0.6329 \\
\text { Product reference: } \mathrm{p}=0.0069 \\
\text { Multi-channel sales: } \mathrm{p}=0.0000 \\
\text { Lower price of products and services: } \mathrm{p} \\
=0.3499 \\
\text { Wider range of products: } \mathrm{p}=0,2793 \\
\text { Unlimited time of purchase: } \mathrm{p}=0.9912\end{array}$ & 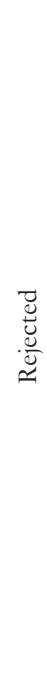 \\
\hline PHg): & $\begin{array}{l}\text { The type of e-commerce stra- } \\
\text { tegy is not influenced by the } \\
\text { quality of the determinants of } \\
\text { online shopping behavior.* } \\
\text { *Testing this hypothesis was } \\
\text { realized for each separate tes- } \\
\text { ted determinant. Some of the- } \\
\text { se determinants were rejected } \\
\text { and some not rejected, howe- } \\
\text { ver this hypothesis was tested } \\
\text { as a whole for } 15 \text { identified de- } \\
\text { terminants in summary, there- } \\
\text { fore, this hypothesis was as a } \\
\text { whole rejected. }\end{array}$ & 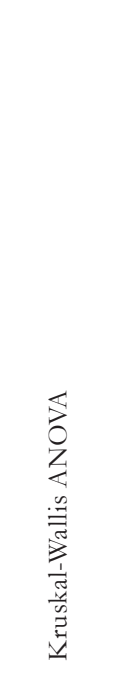 & $\begin{array}{l}\text { E-commerce security: } \mathrm{p}=0.0250 \\
\text { Payment systems in e-commerce: } \\
\mathrm{p}=0.8947 \\
\text { Method and speed of delivery of goods: } \\
\mathrm{p}=0.5252 \\
\text { Webdesign: } \mathrm{p}=0.1503 \\
\text { Customer service: } \mathrm{p}=0.3362 \\
\text { E-shop credibility: } \mathrm{p}=0.1108 \\
\text { E-shop certification: } \mathrm{p}=0.7961 \\
\text { Online visualization and product descrip- } \\
\text { tion: } \mathrm{p}=0.3878 \\
\text { Added value to online purchase: } \\
\mathrm{p}=0.5647 \\
\text { E-shop reference: } \mathrm{p}=0.2369 \\
\text { Product reference: } \mathrm{p}=0.6574 \\
\text { Multi-channel sales: } \mathrm{p}=0.0427 \\
\text { Lower price of products and services: } \mathrm{p} \\
=0.4689 \\
\text { Wider range of products: } \mathrm{p}=0.7193 \\
\text { Unlimited time of purchase: } \mathrm{p}=0.0553\end{array}$ & 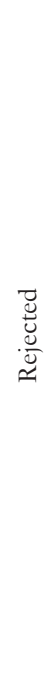 \\
\hline PHh): & $\begin{array}{l}\text { The quality of determinants of } \\
\text { online shopping behavior eva- } \\
\text { luated on the basis of critical } \\
\text { analysis is evenly distributed }\end{array}$ & 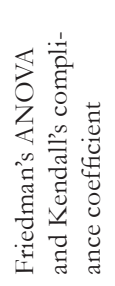 & $\mathrm{p}=0.0000$ & 芯 \\
\hline
\end{tabular}




\begin{tabular}{|l|l|l|l|l|}
\hline PHi): & $\begin{array}{l}\text { There is no relationship } \\
\text { between the importance of the } \\
\text { different phases of strategic } \\
\text { management in e-commerce } \\
\text { and the quality of online de- } \\
\text { terminants of online shopping } \\
\text { behavior. }\end{array}$ & $\begin{array}{l}\text { Multiple p-values in correlation matrix, } \\
\text { since } \mathrm{p} \leq \alpha\end{array}$ & \\
\hline
\end{tabular}

*Method of hypothesis verification

** Conclusion of hypothesis verification

\section{DISCUSSION}

Based on the research, all the determinants of online shopping behavior are part of the strategic management process in e-commerce, and all play a key role in designing and implementing e-commerce strategy in the long-term development of companies primarily focused on e-commerce. In part these conclusions have been identified in other previous research (Pilík, 2012; Pilík et al., 2017a, Pilík et al., 2017b; Prashant, 2009; Richard et al., 2010; Huseynov \& Yildirim, 2016; Hallikainen \& Laukkanen, 2018; Kumar \& Dange, 2012; Huang \& Benyoucef, 2013).

Descriptive statistics and the verification of the research hypotheses in this field have revealed a relationship between the size of an enterprise and the quality of determinants of online shopping behavior. These research studies have also highlighted the possible differences in selected determinants of e-commerce in terms of the size of companies (Singh \& Keating, 2018; Oliva et al., 2003; Kao \& Decou, 2003; Yanes-Estévez et al., 2020; Lynda et al., 1996). Furthermore, it has been determined that the evaluation of the quality and importance of determinants of online shopping behavior is not evenly distributed. Nevertheless, despite the findings shown in (Prashant, 2009; Richard et al., 2010; Prashant, 2009; Kim et al., 2009; Wang et al., 2010; Roca et al., 2009; Martín \& Camarero, 2009; Makwana et al., 2017; Darsono et al., 2019; Li et al., 2019; Forman, 2005; Doern \& Fey, 2006; Power, 2005; Filson, 2004) that the same priorities should be given to the determinants of e-commerce when creating and implementing an e-commerce strategy, our research revealed findings contradicting this view.

The research of (Pilík, 2012; Pilík et al., 2017a, Pilík et al., 2017b; Prashant, 2009; Richard et al., 2010; Huang \& Benyoucef, 2013; Roberts \& Zahay, 2013; Lu et al., 2015; Huseynov \& Yildirim, 2016; Hallikainen \& Laukkanen, 2018; Dai, 2012; Choshin \& Ghaffari, 2017; Kumar \& Dange, 2012; Singh \& Sailo, 2013; Cetina et al., 2012; Safa \& Ismail, 2013; Hernández et al., 2010; Makwana et al., 2017; Darsono et al., 2019; Li et al., 2019) identified the determinants of online shopping behavior from the perspective of online consumers. Nevertheless, no research so far to our knowledge has dealt with the determinants of online shopping behavior from the perspective of the online retailer. For this reason, the present paper has attempted to identify the importance and impact of determinants of online shopping behavior on the strategic management process in e-commerce. We have revealed that the e-commerce companies of our study could not survive in the long-term period without considering the determinants of online shopping behavior in designing and implementing an e-commerce strategy. These findings have also been identified 
in previous researches (Singh \& Keating, 2018; Zhao et al., 2019; Wang et al., 2020; Leung et al., 2018; Broome, 2016; Hallikainen \& Laukkanen, 2018; Huang \& Benyoucef, 2013; Kim \& Park, 2013).

\section{CONCLUSION}

In summary, the determinants of online shopping behavior play an important role in the process of designing and implementing an e-commerce strategy, and all companies are aware of their importance. The results of this paper have shown an impact of determinants of online shopping behavior on the strategic management process in e-commerce, i.e. determinants of online shopping behavior play the key role in a successful strategic management process as well as in the long-term competitiveness and development of e-commerce companies. To succeed in the ecommerce environment, e-commerce companies must take into account all the determinants of online shopping behavior identified through primary and secondary research in the e-commerce strategic management process. These findings could thus be used as support for other research activities in this field as well as to create guidance strategies for digital managers and owners to improve the effectiveness of strategic management process in e-commerce competitiveness. The main benefits of the research are the identification of determinants of online shopping behavior from the perspective of e-commerce companies and its impact on the process of strategic management in e-commerce competitiveness. Although we have conducted a comprehensive research study in e-commerce, some limitations must be highlighted. Our research sample is limited to the e-commerce companies in the Czech Republic, therefore in a different region results may vary. Other research activities could focus on the comparison of identified outcomes in different countries. The research sample is also limited to stable and established e-commerce companies, i.e. start-up companies were not included, as they often lack stable financial results and a history in e-commerce. Other research could focus solely on start-up e-commerce companies. Our research focused on identifying the importance of the determinants of online shopping behavior. This importance was evaluated on a $1-5$ scale of managers and owners of businesses. Evaluations conducted on other stakeholders, e.g. middle and low management, may show varying results. Additional research may focus on the identification of differences between top management and middle and low management. A final limitation might be identified based on the strategy of describing the determinants of online shopping behavior in the process of strategic management in e-commerce. In practice, different or additional determinants might be identified if e-commerce companies are asked directly about these matters. The identification of these determinants in the research derives solely from theoretical background. Further research could focus on identification of further possible determinants as specified by e-commerce companies.

\section{Acknowledgement}

This paper was prepared through the IGA project of Mendel University in Brno entitled "Importance of SME Strategy in Regional Development" with the registration number FRRMS - IGA $-2020 / 004$. 


\section{References}

1. Bandara, R., Fernando, M., \& Akter, S. (2019). Explicating the privacy paradox: A qualitative inquiry of online shopping consumers. Journal of Retailing and Consumer Services, 52. 220-233. https://doi.org/10.1016/j.jretconser.2019.101947

2. Broome, P. A. (2016). Conceptualizing the foundations of a regional e-commerce strategy: Open networks or closed regimes? The case of CARICOM. Cogent Business \&Management, 3 (1), 1139-1441. https://doi.org/10.1080/23311975.2016.1139441

3. Castaneda, J. A., Rodriguez-Molina, M. A. \& Martínez, T. L. (2009). Attitude's hierarchy of effects in online user behavior. Online Information Review, 33 (11), 7-21.

https://doi.org/10.1108/14684520910944364

4. Cetina, I., Munthiu, M.-C. \& Radulescu, V. (2012). Psychological and Social Factors that Influence Online Consumer Behavior. Procedia - Social and Behavioral Science, 62, 184-188. https://doi.org/10.1016/j.sbspro.2012.09.029

5. Choshin, M., \& Ghaffari, A. (2017). An investigation of the impact of effective factors on the success of e-commerce in small- and medium-sized companies. Computers in Human Behavior, 66 (1), 67-74. https://doi.org/10.1016/j.chb.2016.09.026

6. Chouhan, R. (2017). E-Business and E-Commerce Management (Strategy, Implementation and Practice). Pacific Business Review International, 9(10), 135-136.

7. Dai, Z. (2012). The Study on the Influence about Trust to Online Shopping Behavior. In: Eleventh Wuban International Conference on e-Business Wuban: Association for Information Systems, $24-29$.

8. Darsono, J. T., Prihantono, E. Y. \& Kasim, E. S. (2019). Strategic Policies for Small and Medium Businesses in marketing through E-commerce. Entrepreneurship and Sustainability Issues, 7 (2), 1230-1245. https://doi.org/10.9770/jesi.2019.7.2(30)

9. Doern, R. R., \& Fey, C. F. (2006). E-commerce developments and strategies for value creation: The case of Russia. Journal of World Business, 41 (4), 315-327.

https://doi.org/10.1016/j.jwb.2006.08.001

10. Filson, D. (2004). The Impact of E-Commerce Strategies on Firm Value: Lessons from Amazon.com and Its Early Competitors. The Journal of Business, 77 (2), 135-154. https://doi.org/10.1086/381640

11. Forman, C. (2005). The corporate digital divide: Determinants of Internet adoption. Management Science, 51(4), 641-654. https://doi.org/10.1287/mnsc.1040.0343

12. Hallikainen, H., \& Laukkanen, T. (2018). National culture and consumer trust in ecommerce. International Journal of Information Management, 38 (1), 97-106. https://doi.org/10.1016/j.ijinfomgt.2017.07.002

13. Hernández, B. et al. (2010). Customer behavior in electronic commerce: The moderating effect of e-purchasing experience. Journal of Business Research, 63, 964-997.

https://doi.org/10.1016/j.jbusres.2009.01.019

14. Huang, Z., \& Benyoucef, M. (2013). From e-commerce to social commerce: A close look at design features. Electronic Commerce Research and Applications, 12 (4), 246-259. https://doi.org/10.1016/j.elerap.2012.12.003 
15. Huseynov, F., \& Yildirim, S. Ö. (2016). Internet users' attitudes toward business-to-consumer online shopping: A survey. Information Development, 32 (3), 452-465.

https://doi.org/10.1177/0266666914554811

16. Ivanova, A. S., Holionko, N., Tverdushka, T. B. \& Yakymchuk, A. (2019). The Strategic Management in Terms of an Enterprise's Technological Development. Journal of Competitiveness, 11 (4), 40-56. https://doi.org/10.7441/joc.2019.04.03

17. Kao, D., \& Decou, J. (2003). A strategy-based model for e-commerce planning. Industrial Management \& Data Systems. 103(4), 238-252. https://doi.org/10.1108/02635570310470638

18. Kim, H., Lee, D., \& Ryu, M. H. (2018). An Optimal Strategic Business Model for Small Businesses Using Online Platforms. Sustainability, 10 (3), 1-11. https://doi.org/10.3390/su10030579

19. Kim, J., Jin, B. \& Swinney, J. L. (2009). The role of e-tail quality, e-satisfaction and e-trust in online loyalty development process. Journal of Retailing and Consumer Services, 16, 239-247. https://doi.org/10.1016/j.jretconser.2008.11.019

20. Kim, K., Hong, E., \& Rho, S. (2013). The study of defined shopping factors affecting trust building and service performance in financial management systems. Mathematical and Computer Modelling, 58 (1), 38-48. https://doi.org/10.1016/j.mcm.2012.06.006

21. Kim, S., \& Park, H. (2013). Effects of various characteristics of social commerce (s-commerce) on consumers' trust and trust performance. International Journal of Information Management, 3 (2), 318-332. https://doi.org/10.1016/j.ijinfomgt.2012.11.006

22. Kubanová, J. (2004). Statistické metody pro ekonomickou a technickou praxi. Pardubice: Univerzita Pardubice.

23. Kumar, V., \& Dange, U. (2012). A Study of Factors Affecting Online Buying Behavior: A Conceptual Model. SSRN Electronic Journal, 2 (2). 174-188.

https://doi.org/10.2139/ssrn.2285350

24. Lee, M. K. O., \& Turban, E. (2001). A trust model for consumer internet shopping. International Journal of Electronic Commerce, 6 (1), 75-91.

25. Leung, K. H., Choy, K., Siu, P. K. Y., Ho, G. T. S., Lam, H. Y., \& Lee, C. K. M. (2018). A B2C e-commerce intelligent system for re-engineering the e-order fulfilment process. Expert Systems with Applications, 91, 386-401. https://doi.org/10.1016/j.eswa.2017.09.026

26. Li, H. X. (2015). Research on the path selection of electronic commerce industry development. Shandong Social Science, 1 (9), 125-129.

27. Li, X., Li, T. P., Li, H., Qui, J. M. \& Hu, L., J. (2019). Research on the Online Consumption Effect of China's Urbanization under Population Aging Background. Sustainability, 11 (16), 43-49. https://doi.org/10.3390/su11164349

28. Long, Z. (2017). Research on Competitive Strategies of E-commerce Companies from the Perspective of Internet Economy. Agro Food industry Hi-tech, 28(3) 3436-3439.

29. Lu, J. D., Wu, M., Mao, W., \& Zhang, G. (2015). Recommender system application developments: A survey. Decision Support Systems, 74, 12-32.

https://doi.org/10.1016/j.dss.2015.03.008 
30. Lumpkin, G. T., Droege, S. B., \& Dess, G. G. (2002). E-Commerce Strategies: Achieving Sustainable Competitive Advantage and Avoiding Pitfalls. Organizational Dynamics, 30 (4), 325-340. https://doi.org/ 10.1016/S0090-2616(02)00065-7

31. Lynda, M. A., Clyde, W. H., Franz, J. R., \& Andrew, B. W. (1996) Electronic commerce: Building blocks of new business opportunity. Journal of Organizational Computing and Electronic Commerce, 10 (1), 1-10. https://doi.org10.1080/10919399609540264

32. Makwana, K., Pathak, A. \& Sharma, P. (2017). What Drives Consumers to Shop Online. IOSR Journal of Computer Engineering, 3 (2), 42-47.

33. Martín, S. S., \& Camarero, C. (2009). How perceived risk affects online buying. Online Information Review, 33 (4), 629-654. https://doi.org/10.1108/14684520910985657

34. Oliva, R., Sterman, J. D., \& Giese, M. (2003). Limits to growth in the new economy: exploring the "get big fast" strategy in e-commerce. System Dynamics Review, 19 (2), 83-117. https://doi.org/10.1002/sdr.271

35. Onate, C. G. (2016). E-commerce in Spain and the Strategy of Online Branding: The Apps As Platform for Shopping. Revista Comunicacao Midiatica, 11 (3) 230-250.

36. Pereira, H. G., Salgureiro, M., F. \& Rita, P. (2016). Online purchase determinants of loyalty: The mediating effect of satisfaction in tourism. Journal of Retailing and Consumer Services, 30 (1), 279-291. http://dx.doi.org/10.1016/j.jretconser.2016.01.003

37. Perrigot, R., \& Pénard, T. (2013). Determinants of E-Commerce Strategy in Franchising: A Resource-Based View". International Journal of Electronic Commerce, 17 (3), 109-130. https://doi.org/10.2753/JEC1086-4415170305

38. Petrtyl, J. (2012). Security and Trustworthiness as Drivers of E-shop Competitiveness (Opinions of Young Customers). Journal of Competitiveness, 4 (1), 83-97. https://doi.org/10.7441/joc.2012.01.07

39. Pilík, M. (2012). Online Shopping on B2C Markets in the Czech Republic. Journal of Competitiveness, 4 (4), 37-49. https://doi.org/10.7441/joc.2012.04.03

40. Pilík, M., Klimek, P., \& Juřičková E. (2017b). Comparison Shopping Agents and Czech Online Customers' Shopping Behavior. International Journal of Entrepreneurial Knowledge, 4 (2), 62-69. https://doi.org/10.1515/ijek-2016-0014

41. Pilík, M., Juřičková, E., \& Kwarteng, M. A. (2017a). On-line shopping behavior in the Czech Republic under the digital transformation of economy. Economic Annals-XXI, 165 (5), 119-123. https://doi.org/10.21003/ea.V165-24

42. Power, D. (2005). Determinants of business-to-business e-commerce implementation and performance: a structural model. Supply Chain Management. An International Journal, 10 (2), 96-113. https://doi.org/10.1108/13598540510589179

43. Prashant, P. (2009). The role of trust in e-commerce relational exchange: A unified model. Information \& Management, 46 (4), 213-220. https://doi.org/10.1016/j.im.2009.02.003

44. Raosoft. (2018). Sample size calculator. Retrieved February 25, 2018, from: http://www.raosoft. com/samplesize.html. 
45. Richard, M. O., Chebat, J.-Ch. \& Yang, Z. \& Putrevu, S. (2010). A proposed model of online consumer behavior: Assessing the role of gender. Journal of Business research, 63, 926-934. https://doi.org/10.1016/j.jbusres.2009.02.027

46. Roberts, M., L., \& Zahay, D., L. (2013) Internet marketing: integrating online and offline strategies. 3rd ed. Australia: South-Western Cengage Learning.

47. Roca, J. R., García, J. J. \& de la Vega, J. J. (2009). The importance of perceived trust, security and privacy in online trading systems. Information Management \& Computer Security, 17 (2), 96113. https://doi.org/ 10.1108/09685220910963983

48. Safa, N. S., \& Ismail, M. A. (2013). A customer loyalty formation model in electronic commerce. Economic Modelling, 35, 559-564. http://dx.doi.org/10.1016/j.econmod.2013.08.011

49. Singh, A. K., \& Sailo, M. (2013). Consumer Behavior in Online Shopping: A Study of Aizawl. International Journal of Business \& Management Research, 1 (3), 45-49.

50. Singh, N., \& Keating B. M. (2018). Hyper-localizing e-Commerce Strategy: An Emerging Market Perspective. Emerging Markets from a Multidisciplinary Perspective. Springer International Publishing AG.

51. Wang, F., Yang, Y., Geofrey K. F. T., \& Yang, L. (2019). Analysis of launch strategy in cross-border e-Commerce market via topic modeling of consumer reviews. Electronic Commerce Research, 19 (4), 1-22. https://doi.org/10.1007/s10660-019-09368-1

52. Wang, Y. J., Hernandez, M.D. \& Minor, M.S. (2010). Web aesthetics effects on perceived online service quality and satisfaction in an e-tail environment: The moderating role of purchase task. Journal of Business Research, 63, 935-942.

https://doi.org/ 10.1016/j.jbusres.2009.01.016

53. Wu, I.-L., \& Wu, S. M. (2015). A strategy-based model for implementing channel integration in e-commerce. Internet Research, 25 (2), 239-261. https://doi.org/10.1108/IntR-10-2013-0212

54. Yanes-Estévez, V., García-Pérez, A. M. \& Oreja-Rodríguez, J. R. (2018). The Strategic Behaviour of SMEs. Administrative Sciences, 8 (61), 1-21.

https://doi.org/10.3390/admsci8040061

55. Yi, S. (2016). E-commerce strategy for agricultural product transaction market based on information asymmetry. Agro Food industry Hi-tech, 27 (6), 138-143.

56. Zhao, J., Liu, H. \& Xue, W. (2019). PEST Embedded SWOT Analysis on China's

E-Commerce Industry Development Strategy. Journal of Electronic Commerce in Organizations, 17 (2), 55-68. https://doi.org/10.4018/JECO.2019040105

57. Zhao, Y., Zhou, Y., \& Deng, W. (2020). Innovation Mode and Optimization Strategy of B2C E-Commerce Logistics Distribution under Big Data. Sustainability, 12 (8), 73-81. https://doi.org/10.3390/su12083381

58. Zwass, V. (2003). Electronic commerce and organizational innovation: Aspects and opportunities. International Journal of Electronic Commerce, 7 (3), 7-37. 
Contact information

Veronika Svatosova, Ph.D.

Mendel University in Brno

Faculty of Regional Development and International Studies

Department of Regional and Business Economics

Czech Republic

E-mail:veronika.svatosova@mendelu.cz.

ORCID: 0000-0002-5308-8822 